\title{
DZIENNIKI MARII DĄBROWSKIEJ JAKO ŹRÓDŁO WIEDZY O HISTORII
}

Wiedza o historii... ale cóż to znaczy „historia” rozpatrywana poprzez dzienniki Marii Dąbrowskiej, a więc dzieło niezwykłe, zawierające przecież w znacznej części informacje o codziennych, banalnych i przyziemnych sprawach, przetykane różnego rodzaju refleksjami osoby wprawdzie wyjątkowej, ale niemiarodajnej dla polityki, nauki, filozofii politycznej i ideologii? W samej rzeczy, autorka programowo dystansuje się od życia politycznego w ścisłym tego słowa znaczeniu, a zwłaszcza od partii politycznych, i jej wypowiedzi na tematy polityczne, na przykład z wczesnych lat dwudziestych, można niekiedy określić jako naiwne. Później zresztą się to zmienia, i to dość zasadniczo, od końca lat dwudziestych orientacja autorki pozwala jej wyrobić sobie jasno określoną postawę, a był to okres polaryzacji politycznej, której skutki będą rzutować także na późniejsze postawy i demokratycznej inteligencji, i samej Marii Dąbrowskiej. Przecież jednak nie tylko historyk profesjonalnie zajmujący się dziejami XX wieku, lecz także każdy zainteresowany przeszłością naszego kraju i jego społeczeństwa znajdzie $\mathrm{w}$ dziennikach wielkie bogactwo elementów składających się na obraz minionych lat. Elementów — bo też autorka nie tworzy i nie pozostawia nam jakiejś jednolitej koncepcji czy to sensu współczesnego świata, czy to choćby przemian historycznych zachodzących w ciągu półwiecznej epoki powstawania dzienników. Mogą więc dzienniki służyć i w pewnym zakresie od kilku dziesięcioleci służą — jako materiał do budowy syntetycznego obrazu świata, Polski, dziejów — tak przez każdego ich czytelnika, jak i przez uczonego.

Autorka zdawała sobie sprawę ze znaczenia swych dzienników. Pisała: „Mam do stracenia tylko jedną jedyną, ale dla mnie piekielnie ważną rzecz — te moje dzienniki. Nie aby miały jakąkolwiek wartość literacką, ale że przez

Adres do korespondencji: Instytut Historii PAN, Rynek St. Miasta 29/31, 00-272 Warszawa; e-mail: j-zarnowski@wp.pl 
nie tylko jestem w stanie wystąpić kiedyś, choćby po śmierci, jako świadek czasów" (10 V 1956). Tak się właśnie stało, i po stokroć dla nas szczęśliwie.

Historia, o której tu mowa, to - owszem - historia wojen, systemów politycznych na świecie - zwłaszcza jednak w Polsce - i przełomów w życiu państwowym, ale w znacznie większej mierze historia społeczeństwa, jego życia codziennego, jego radości i smutków, obaw i lęków, czasem także - co prawda rzadziej - jego triumfów czy choćby satysfakcji. Dzienniki wprowadzają jeszcze jeden wymiar historii - wymiar indywidualny i rodzinny, wraz $z$ całą gamą życia uczuciowego, nastrojów, konfliktów postaw i przekonań, przeobrażeń psychologicznych, którym $\mathrm{w}$ ciągu tego półwiecza podlegają nie tylko jednostki, ale także - tylko może w inny nieco sposób - warstwy, grupy i środowiska społeczne, kolejne generacje i wspólnoty wszelkiego rodzaju.

Ten ostatni wymiar, sentymentalno-psychologiczny, zajmuje niewątpliwie najwięcej miejsca $\mathrm{w}$ integralnym tekście dzienników. To właśnie losy i wrażenia osobiste, poglądy, sentymenty i marzenia stanowią na ogół oś i najobszerniejszą część tekstu. Dopiero z czasem sprawy publiczne, zbiorowe, uzyskują bodaj dominującą reprezentację, zawsze jednak przefiltrowane przez zainteresowania, horyzonty i losy własne autorki, jej otoczenia, rodziny, kręgów zawodowych i ideowych, do których należała lub z którymi najczęściej się stykała. Narracja, opowiadanie o wydarzeniach wychodzących poza życie autorki, jej dom, rodzinę i krąg przyjaciół, to w dziennikach czynnik wtórny, niezbędny do poinformowania przyszłego czytelnika, a także siebie samej w przyszłości, po jakimś dłuższym czasie. Autorka przedstawia te wydarzenia raczej niecierpliwie, nieraz wraca do narracji, gdy dochodzi do przekonania, że bez uzupełnień czytelnik nie zrozumie dobrze o co chodzi. Nieraz też zmuszona jest po latach wyjaśniać okoliczności, uzupełniać opowiadanie - niekiedy się to zresztą nie udaje, gdy pamięć nie zachowała odpowiednich informacji.

Mamy tu więc do czynienia $z$ historią widzianą przez pryzmat losu wyjątkowej jednostki, jej własnego środowiska, własnej wrażliwości $-z$ taką historią, w której wielkie wydarzenia polityczne, gospodarcze itp. stanowią raczej tło niż główny wątek. Tło takie przybliża się do czytelnika tylko w momentach wielkich wydarzeń, a także w końcowych partiach dzienników. Inaczej być nie mogło, gdyż nadeszły lata drugiej wojny światowej, a potem czasy „Polski Ludowej” i PRL. Żadna jednostka czy rodzina nie była w stanie wówczas zachować dystansu w stosunku do wydarzeń „zewnętrznych” wobec życia codziennego, co było w pewnym stopniu możliwe w czasie dwudziestoletniego międzywojennego pokoju. Te „zewnętrzne” wydarzenia określały teraz bezpośrednio byt i losy jednostek oraz rodzin, wciągały w swój wir nawet najbardziej indyferentnych.

W ostatnim z wymienionych okresów, po drugiej wojnie światowej, autorka cieszyła się znacznym autorytetem społecznym, wychodzącym daleko poza świat literatury, co kazało postrzegać ją jako ewentualnego partnera wła- 
dzy i nie pozwalało lekceważyć. Ta okoliczność zmieniała również perspektywy i wewnętrzne proporcje zjawisk notowanych w dziennikach. Polityka na szczeblu centralnym interesuje się autorką, władza zaprasza ją na różne spotkania, uroczystości, imprezy, rozmawia z nią i oczekuje takich czy innych zachowań, zresztą nie bez rezultatu. W ten sposób sfera, która kiedyś pozostawała w swobodnie omawianym tle, zbliża się do Dąbrowskiej, zbliża się niebezpiecznie, ale też i wprowadza do dzienników nowy wymiar.

Przez znaczną część okresu międzywojennego i potem w latach po drugiej wojnie światowej dzienniki dają wyraz ambiwalencji autorki w stosunku do państwa i władzy. Problem pojawia się wtedy, gdy polityka Piłsudskiego i sanacji budzi u niej i u całej lewicy niepodległościowej coraz większe zastrzeżenia. A jednocześnie w strukturach obozu rządzącego pozostaje bardzo wielu znajomych, w niektórych ogniwach odgrywają główną rolę dawni uczestnicy tych samych dyskusji, tych samych działań, tych samych organizacji, w których autorka brała udział. Nie ma powodu, by się od nich odcinać, zwłaszcza gdy się wierzy, że jednak gdzieś w głębi płynie nurt pracy pożytecznej dla narodu, państwa, społeczeństwa. Niekiedy trzeba prosić ich o taką czy inną przysługę osobistą, którą stanowisko urzędowe starych przyjaciół ułatwia. Budzi to niekiedy refleksje, niepokój, konflikty, wyrzuty sumienia. W poważniejszych sprawach (na przykład rewizja u Stanisława Stempowskiego w związku z likwidacją wolnomularstwa) uzyskuje się pomoc wpływowych przyjaciół, tym bardziej można z niej korzystać dla starań o paszport (dla dzisiejszych czytelników rzecz słabo zrozumiała, ale przecież pełnopłatny paszport kosztował przed wojną bardzo wysoką kwotę 500 złotych, a przyznanie „paszportu ulgowego” zależało od widzimisię władz) i o podobne sprawy zawisłe od administracji. Ale do $1939 \mathrm{r}$. konflikty sumienia na tym tle nie były poważne, $\mathrm{w}$ końcu przedstawiciele formacji genetycznie związanej z inteligencją niepodległościową coś tam jednak prawie do końca dwudziestolecia znaczyli i sam krytykowany reżim sanacyjny nie był przez to jakoś zasadniczo obcy i wrogi.

Sytuacja zmieniła się po 1945 r. Nowy reżim traktuje Dąbrowska jako narzucony i zależny od Rosji, jako formę kontynuacji przemocy „Moskali” wobec Polski, przemocy, z którą jej pokolenie zmierzyło się jeszcze za rządów caratu. Ale formułę społeczną - początkowo niejasno podawaną, a nawet socjalizm (do tego terminu inteligencja niepodległościowa żywiła szacunek, w końcu przeszła przez etap socjalizmu przynajmniej w stylu Piłsudskiego) - uważała za nadającą się do dyskusji, choć realizowaną przemocą, w drodze dyktatury, z pogardą dla wolności i jednostki. Długo po drugiej wojnie światowej w świadomości starszego pokolenia funkcjonowało także zasadnicze rozczarowanie kapitalizmem wzmocnione przez tragiczny kryzys gospodarczy lat trzydziestych. To umacniało złudzenia co do perspektyw gospodarki kierowanej, „planowej", która w latach trzydziestych była wręcz dogmatem, nie tylko w Polsce, ale i w twierdzach ówczesnego świata zachodniego, gdyż kryzys przypisywano liberalizmowi. 
Rządzący Polską po 1945 r. nie należą do tej samej formacji społeczno-historycznej co pisarka, odmiennie niż przed 1939 r., i nawet gdy trochę flirtuje ona $z$ władzą, to jednak ludzie tej władzy (z minimalnymi wyjątkami na średnich i niższych szczeblach, a także w kręgu literatury) to ludzie obcy, nawet gdy pisze się o nich bez potępienia czy z cząstkową aprobatą.

Ambiwalencja widoczna w dziennikach Dąbrowskiej po 1945 r. nie była tylko jej specyficznym problemem. W znacznym stopniu odbijała dwoistą świadomość znacznej i bodaj coraz liczniejszej części inteligencji, w której szeregi szerokim strumieniem wlewały się teraz żywioły "ludowe” - niby zgodnie z pragnieniami społeczników z początków wieku. Ta ambiwalencja ujawniła się w pierwszych latach Polski Ludowej, gdy instytucje państwowe początkowo imitowały „demokrację", a po szaleństwie stalinizacji (w której programie gospodarczo-społecznym też zresztą doszukiwano się jakichś „elementów pozytywnych") powstały znów podobne jak przedtem problemy: państwo poststalinowskie znów dusi wszelkie zalążki demokracji i służy Moskwie, ale przecież to Zachód zgodził się na dominację ZSRR na Wschodzie, kapitalizm nie daje Polsce żadnych perspektyw, a wreszcie Rosja jest w końcu gwarantem Ziem Zachodnich dla Polski. A więc patriota nienawidzi Moskali (termin już przestarzały, mówi się o „ruskich”) i rusyfikacji, ale zarazem stara się wykorzystać istniejące możliwości społeczne i historyczne dla dobra narodu i społeczeństwa.

Wystarczająco już podkreśliliśmy indywidualny charakter tej wizji historii, która znalazła odbicie w dziennikach Marii Dąbrowskiej. A przecież nie jest to cała prawda o tym przecennym dokumencie. W końcu autorka, którą tu nazwano parokrotnie jednostką wyjątkową, była także członkiem społeczeństwa, żyjącym w gronie rodziny, krewnych, dawnych i nowych przyjaciół, pochodzących ze środowisk literacko-artystycznych oraz z kręgów niepodległościowych, kiedyś połączonych wspólnymi ideami społecznymi i politycznymi, z czasem rozproszonych po różnych orientacjach ideowych i politycznych.

Poglądy i punkty widzenia reprezentowane przez autorkę nie brały się oczywiście tylko z jej własnych przemyśleń, lektur, spostrzeżeń. Nie dzieje się tak nigdy, gdyż jednostka, nawet najwybitniejsza, może sobie sama wyrobić pogląd tylko na ograniczoną liczbę zjawisk. Polega więc na opiniach przede wszystkim swego otoczenia rodzinnego i społecznego. Dlatego nie zapominając o tym, że mamy do czynienia $z$ jednostką wybitną, o rozwiniętym indywidualizmie, wolno nam patrzeć na wypowiedzi Marii Dąbrowskiej jako na wyraz opinii społecznej, zwłaszcza niektórych, a zarazem zmieniających się w czasie środowisk.

Z najbardziej ogólnej perspektywy, wolno przyporządkować Marię Dąbrowską do formacji inteligenckiej, do polskiej inteligencji XX wieku. Oczywiście nie warto nawet rozważać, w jakim stopniu konkretne jej poglądy czy reakcje były w danym momencie podzielane przez tych, którzy zaliczali się wówczas do środowiska inteligenckiego albo których współczesny badacz ex post zaliczy do tej warstwy. Zapewne większość jednostek należących do tej kategorii nie uznałaby poglądów czy reakcji autorki dzienników za swoje, zwłaszcza przed 
1939 r., ale nie zmienia to ani na jotę naszego przekonania, że właśnie ona przedstawia najbardziej autentyczne reakcje czy myśli ówczesnej, a zresztą nie tylko ówczesnej polskiej inteligencji.

Albowiem formacja społeczno-ideowa, z której wyszła Maria Dąbrowska, a która ukształtowała się na przełomie XIX i XX wieku, określana jako kierunek niepodległościowy, to najbardziej inteligenckie środowisko ówczesnej polskiej klasy wykształconej. To środowisko, skupione wokół Józefa Piłsudskiego i dlatego zakotwiczone w obozie socjalistycznym i radykalno-demokratycznym, podejmuje bezpośrednią walkę o niepodległość umożliwioną przez wybuch wojny światowej w 1914 r., popiera dążenia integracyjne Piłsudskiego i staje przy nim w czasie odbudowy państwa polskiego w 1918 r. Wybory do Sejmu Ustawodawczego to okres odpływu różnych środowisk inteligenckich do nacjonalistycznej endecji i w mniejszym stopniu do innych nurtów ideowych, niepodległościowa inteligencja natomiast nie potrafi wytworzyć samodzielnej, liczącej się siły politycznej i pozostaje w zawieszeniu, nadal orientując się na Komendanta-Marszałka, a po zamachu majowym popiera nowy reżim, ale wkrótce jej znaczna część przechodzi do opozycji, piętnując odwrót sanacji od demokracji i programu społecznego.

Inteligencja niepodległościowa to jednak nie tylko i nie przede wszystkim kategoria złączona dążeniami politycznymi - z czasem pozostały $z$ nich głównie przyjaźnie i wspomnienia - ale także kategoria społeczno-obyczajowa, która stała się przewodnikiem idei demokratycznego społeczeństwa, związków z Europą i jej demokratyczną kulturą. Wywarła na nią wpływ epoka, w której powstała - a była to epoka radykalizmu, postępów demokracji, laicyzmu, a zarazem wezbrania dążeń niepodległościowych i patriotycznych. Inteligencja niepodległościowa była wówczas tą częścią polskiej klasy wykształconej, która odcinała się $\mathrm{z}$ jednej strony od nacjonalizmu - ten zapanował w znacznym stopniu nad społeczeństwami Europy w okresie międzywojennym i w swym najskrajniejszym odłamie wytworzył faszyzm - i od skrajnych zwolenników „rewolucji proletariackiej”, w tym czasie był to synonim komunizmu.

Formacja ta, jeśli nawet bezsilna politycznie, nie przeszła pod patronat skrajnych i antydemokratycznych ugrupowań politycznych i pozostała wierna nabytym przed pierwszą wojną światową ideałom: demokracji, tolerancji, walki o równouprawnienie społeczne i o niezbędne reformy społeczne, ale również niezależności i niepodległości odbudowanego z trudem państwa, rozumianego jako emanacja narodu, społeczeństwa, a nie jako własność uzurpatorskich „elit” i klik.

Formacja, do której należała Maria Dąbrowska, już w okresie powstawania, a więc na przełomie wieków, przyjęła zasadę łączności z Europą, to jest z cywilizacją zachodnią, i dostrzegła wynikającą z niej potrzebę modernizacji Polski i jej społeczeństwa. Ta grupa inteligencji w okresie międzywojennym i w jakimś sensie w całym XX wieku pełniła rolę pierwszego i zapewne najważniejszego przewodnika wzorów cywilizacyjnych i intelektualnych Zachodu 
— środowiska, z którego rozchodziły się owe wzory po innych, szerszych i masowych warstwach społeczeństwa. W tym wypadku rola i posłannictwo literatury miały decydujące znaczenie i autorka dzienników była postacią na tym polu wielce zasłużoną. Przy tym cały ten krąg społeczno-polityczno-towarzyski, w którym kształtowała się inteligencja niepodległościowa, pochodził przecież ze sfer społecznych najbardziej zakorzenionych w historii i w polskości. Mam na myśli „szlachecko-demokratyczny” rodowód tej formacji. Kto w tym złożonym przymiotniku upatrywałby sprzeczności, niech sobie przypomni historię „demokracji szlacheckiej” od Insurekcji i emigracji politycznej do rewolucyjnej Francji przez Towarzystwo Demokratyczne aż do Czerwonych w 1863 r., skąd już prosta droga do „obozu niepodległościowego”.

Dlatego w naszym pojęciu wypowiedzi autorki dzienników to nie tylko słowa Marii Dąbrowskiej, ale także głos polskiej inteligencji, a przynajmniej jej najbardziej rdzennie in teligenckiego, a ideowo najważniejszego środowiska.

Reakcje autorki dzienników na wszelkiego rodzaju wydarzenia i zwroty polskiej historii półwiecza objętego przez dzienniki, a właściwie nawet dwóch trzecich XX wieku, można śledzić jako historię życia pisarki, ale dla historyka, zwłaszcza skoncentrowanego na dziejach społeczeństwa, szczególnie ciekawe są jej reakcje jako obywatelki, demokratki, patriotki, jako wybitnej i wpływowej członkini polskiej warstwy inteligenckiej, oczywiście także jako intelektualistki, literatki, wybitnej przedstawicielki warstwy oświeconej. Pod koniec życia Dąbrowska pojawia się na obrzeżach nowej komunistycznej warstwy czy „elity” politycznej, oczywiście nie jako uczestnik gry politycznej, lecz jako element otoczenia nowej władzy, który ma ją uwiarygodnić. Nie jest to jednak jakaś samodzielna i charakterystyczna dla niej rola. Jedynie odzwierciedlenie meandrów i powikłań historii polskiej warstwy inteligenckiej.

W późniejszych latach, zwłaszcza po drugiej wojnie światowej, sytuacja się skomplikowała i z dawnej „inteligencji niepodległościowej” pozostały już tylko, zwłaszcza w kraju, różnie rozmieszczone i rozrzucone jednostki. Niektóre idee pozostały jednak żywe, przede wszystkim myśl o połączeniu programu niepodległościowego i społecznego, zadanie w warunkach dominacji sowiecko-rosyjskiej i narzuconego komunizmu utopijne, ale po kryzysie 1956 r. jakby na nowo postawione $\mathrm{w}$ świadomości szerokich warstw świadomego społeczeństwa, zwłaszcza w świadomości nielicznych już przedstawicieli formacji „niepodległościowej". Przebija się ona przez coraz bardziej zdegenerowany system aż do lat 1980-1989. U ich progu, w okresie „Solidarności”, te zasady wydawały się oczywiste i powszechnie podzielane.

Marii Dąbrowskiej dane było obserwować te procesy społeczne tylko przez niepełne dziesięciolecie po Październiku 1956 r. Powstaje pytanie, czy formacja historyczna polskiej inteligencji, którą scharakteryzowaliśmy jako centralną dla całej tej warstwy, znalazła przedłużenie w czasach, gdy pisarki nie było już wśród żywych i w jakich środowiskach mielibyśmy jej upatrywać. 
Pierwszym i zasadniczym walorem dzienników dla historyka jest odzwierciedlenie $\mathrm{w}$ nich postaw najbardziej charakterystycznych dla polskiej inteligencji. Jeszcze raz podkreślimy, że nie ma tu mowy o jakichś statystycznie uchwytnych postawach większości lekarzy, aptekarzy, adwokatów, urzędników państwowych i nauczycieli, które mogły w tym czy innym momencie dość jaskrawo odbiegać od wypowiedzi autorki Nocy $i$ dni, lecz chodzi o postawy powtórzmy - najbardziej charakterystyczne dla tej warstwy, wyjątkowo ważnej dla dziejów społecznych Polski, przede wszystkim w ujęciu długofalowym czy nawet historycznym.

Nie można jednak tych zaświadczonych w dziennikach reakcji ograniczyć do jednej tylko warstwy społecznej — inteligencji. W wielu momentach, a zwłaszcza $\mathrm{w}$ chwilach przełomowych, autorka występuje w zapisach jako porte-parole ogółu społeczeństwa polskiego albo jego przeważającej części. Na pewno dzieje się tak w czasach odbudowy państwa pod wodzą Piłsudskiego, w sierpniu 1920 r., tuż po przewrocie majowym, w szerokim zakresie w latach drugiej wojny światowej (nie rozporządzamy jednak tekstem z okresu pobytu autorki we Lwowie w latach 1939-1940, ponadto względy bezpieczeństwa szczególnie wyraźnie i mocno wyjałowiły tekst z lat wojny, zwłaszcza sprzed 1944 r.; co ciekawe - nie odnosimy takiego wrażenia w stosunku do lat stalinizmu; czy zagwarantowanie przez Cyrankiewicza bezpieczeństwa jej mieszkania miało w tym jakiś udział?). Również zapiski z 1956 r. odbijają postawy nie tylko inteligencji, lecz znacznie większej części, a zapewne większości społeczeństwa polskiego. W innych miejscach jednak Dąbrowska bardzo mocno podkreśla, że jej punktu widzenia nie podziela większość współobywateli. Dotyczy to zwłaszcza przeważającej, według niej, w społeczeństwie polskim nienawiści do Rosji i stąd także do Polski Ludowej, gdy tymczasem ona widzi konieczności i pozytywne elementy wiążące się z tą formacją, które należy wykorzystać dla długofalowo pojętego dobra narodu i polskości.

Dla historyka, badającego dzieje Polski i jej społeczeństwa, ciekawe i bardzo pouczające są nie tylko wypowiedzi dotyczące wydarzeń, sytuacji i stanów, w których społeczeństwo polskie znalazło się czy to w początkach i w toku pierwszej wojny światowej, czy to w latach odrodzonego państwa, w czasie okupacji, czy też w PRL. Ważne są również szczegółowe wyjaśnienia warunków kształtowania się i tła tych poglądów i postaw. A motywy te kryją się najczęściej w warunkach i wpływach życia codziennego. Tu dotykamy kwestii stosunku między sformułowanymi przez Dąbrowską sądami o poważnych sprawach, opisami wydarzeń istotnych dla niej i jej bliskich, dla społeczeństwa i kraju a codziennym bytem i pozornie nieistotnymi zwykłymi zabiegami życiowymi. Mam tu na myśli szczegóły budowania otoczenia domowego, wyżywienia, wypoczynku, rozrywki, przelotne spostrzeżenia, wędrówki w czasie pierwszej wojny światowej, zadomowienie się w mieszkaniu na Polnej, przechodzenie od łączenia pracy zawodowej z literaturą do przestawienia się na twórczość literacką jako główną rolę społeczną, wzrost własnego autorytetu 
literackiego i zarazem względnej zamożności w późniejszych latach międzywojennych, po drugiej wojnie przemieszczanie się po Warszawie czy Wrocławiu i między Warszawą a Komorowem - podmiejską rezydencją Marii Dąbrowskiej od 1957 r., podróże krajowe i, z rzadka, zagraniczne. Te pierwsze, „poważne”, treści znalazły się na ogół w wydanych już fragmentach dzienników. Tekst, który możemy przeczytać $\mathrm{w}$ integralnym tekście dzienników, ponad to, co znajduje się w udostępnionym już przed dziesięcioleciem wyborze, ma moim zdaniem kapitalne znaczenie dla zrozumienia i ujęcia syntetycznego obrazu wynikającego z notatek Marii Dąbrowskiej, a poprzez nie - obrazu dwudziestowiecznych dziejów Polski. I to nawet wtedy, gdy pewna część tego pominiętego w dotychczasowych wyborach tekstu to zapisy snów, o których nie możemy powiedzieć $z$ pewnością, $w$ jakim stopniu są wspomnieniem, a w jakim kreacją. Zresztą sny są obecne i w opublikowanych już częściach dzienników.

Nieraz widać wyraźnie, do jakiego stopnia „małe” wydarzenia życia codziennego - na przykład prozaiczne trudności zaopatrzeniowe z okresu drugiej wojny światowej, a potem z czasów stalinowsko-peerelowskich, albo konstatacje dotyczące składu etnicznego aktywu partyjno-państwowego w latach 1945-1956 na podstawie tych czy innych zebrań i spotkań - kumulują się i implikują sądy o charakterze ogólnym. Trzeba przy tym zwrócić uwagę, jak sukcesy w twórczości literackiej i idące za nimi wyższe dochody umożliwiają życie na wyższym poziomie już w latach trzydziestych, choć apogeum powodzenia i awans do elity społecznej także pod względem materialnym to dopiero czasy powojenne, od lat pięćdziesiątych, z bajecznie wysokimi nakładami Nocy $i$ dni i bardzo wysokimi honorariami. Okoliczność ta nie może nie wpływać na obraz świata i samopoczucie autorki. Zresztą dopiero wtedy konsumuje ona sukces z początków lat trzydziestych. Tak jak wnętrze budynku Prezydium Rady Ministrów obejrzała dopiero po drugiej wojnie światowej zaproszona na uroczystości państwowe - przed wojną wstępu tam nie miała - tak o własnym domu z ogrodem przed wojną mogła marzyć, ale marzenie to spełniło się dopiero po wojnie.

Albo weźmy banalne opowiadania o chorobach, pogarszającym się zdrowiu, o lekarzach i szpitalach. W tych fragmentach, w miarę upływu czasu coraz obszerniejszych, w których mowa zresztą nie tylko o autorce, ale i o jej bliskich z grona rodzinnego (Stanisław Stempowski) i zaprzyjaźnionego, znajdujemy nie tylko banalny zapis stanu zdrowia jednostki, zwłaszcza w wieku podeszłym. W notatkach tych, zawartych $\mathrm{w}$ większości $\mathrm{w}$ tekście dotąd nieznanym, odczytujemy kawał historii opieki medycznej, dziejów medycyny i jej faktycznego oddziaływania na życie jednostek, dziejów opieki lekarskiej w Polsce i poziomu lecznictwa - wszystko to widziane oczyma inteligencji żyjącej na poziomie klasy średniej. A przecież to tylko wycinek $z$ historii naturalnej polskiej inteligencji i warstwy wykształconej w tych właśnie latach, obok realiów życia codziennego, komunikacji, ale także ówczesnego horyzontu po- 
znawczego, poziomu orientacji w świecie, przenikania wpływów zagranicznych w dziedzinie życiowej i intelektualnej itd.

Większość tych informacji znajduje się w zasobie dotąd nieopublikowanym, do którego mają dostęp tylko korzystający z integralnego tekstu dzienników Marii Dąbrowskiej.

Po tych ogólnych rozważaniach przejdę przez kolejne lata zapisów w dzienniku, by wymienić choćby niektóre najważniejsze rodzaje informacji ważnych dla rekonstrukcji dziejów Polski, jej społeczeństwa, w mniejszej zaś mierze, ale także - państwa i jego struktur oraz działań.

W najwcześniejszych zapisach dzienników, pochodzących z czasów Wielkiej Wojny, należy podnieść - zwracając przy tym uwagę na deklaracje nieufności wobec polityki - zapis stosunku inteligencji do Józefa Piłsudskiego. W tych wynurzeniach autorki zawiera się i uwielbienie, i późniejsza historia odejścia od Komendanta oraz opozycji wobec niego i jego obozu. W 1918 r. nie tylko inteligencja ufała mu bez zastrzeżeń: „Dziś przyjechał Piłsudski. Teraz doprawdy cała w nim nadzieja" (10 XI). Jest to zarazem zapis dezorientacji i zagubienia najbardziej przecież wykształconej i świadomej części społeczeństwa, widoczne jest to zwłaszcza w odniesieniu do spraw wschodnich i w ogóle dziejących się na wschód od Bugu. Nie może zresztą dziwić niezrozumienie na przykład istoty bolszewizmu w kraju oddzielonym od rzeczywistości przez sprawną niemiecką cenzurę. W świadomości inteligencji twierdzenia pozostające $w$ związku $z$ uprzednim zaangażowaniem $w$ ruchu socjalistycznym czy radykalno-demokratycznym, nieufność wobec burżuazji czy też wilsonowskiego „imperializmu” krzyżują się z aprobatą dla działań na Wschodzie, w wydaniu Dowbora-Muśnickiego schodzących się z ekspedycjami karnymi „polskich panów" przeciw otaczającemu morzu ukraińskich czy białoruskich chłopów działaniami jak najgorzej rokującymi dla polskości na tych terenach, co też późniejsze losy i wypowiedzi autorki dowodnie pokazały.

Od tak zdezorientowanych środowisk trudno byłoby oczekiwać jasnego stosunku do procesów dziejących się ówcześnie w Europie. Stopniowo jednak sytuacja klaruje się i obraz staje się bardziej zgodny z rzeczywistością. Wśród wielu wątków ciekawych dla czytelnika, w tym dla historyka, trzeba wymienić brak jasności w kwestii, czym był bolszewizm - początkowo zupełnie niezrozumiały dla ludzi w środkowej Polsce (zwłaszcza dopóki trwała niemiecka okupacja, cenzura i izolacja od terenów wschodnich), często utożsamiano go po prostu z bandytyzmem. Zresztą w jakimś sensie trafnie pisze Dąbrowska o rosyjskości bolszewizmu, który łączy ze specyficznymi cechami „rosyjskiej duszy" - zboczonym erotyzmem, ekstremizmem anielsko-diabelskim (oscylowanie między skrajnościami). To spostrzeżenia dość częste u nierosyjskich obserwatorów, a nawet banalne, które nie wystarczą do wyjaśnienia tego zjawiska o znaczeniu sekularnym — zjawiska, w którego cieniu znalazł się cały wiek XX. Ale czy dziś nauka może służyć bardziej przekonującymi wyjaśnieniami? 
Dopiero po pewnym czasie, na przełomie lat dwudziestych i trzydziestych $\mathrm{XX}$ wieku powstaje przekonanie, że w Europie i w świecie toczy się generalny bój między dyktaturą a demokracją, i to przekonanie zaczyna przeważać po przewrocie hitlerowskim (czy też po hitlerowskiej Machtübernahme). Na razie pisarka - i zapewne całe jej środowisko - bardzo ostrożnie przygląda się wojnom, dyplomacji i koncepcjom dotyczącym miejsca Polski w Europie, a bardzo wstrzemięźliwie się o nich wypowiada. O tych sprawach głucho w dziennikach, a takie momenty jak zagrożenie Warszawy w sierpniu 1920 r. (Dąbrowska pozostaje na miejscu i nie ucieka na zachód), plebiscyty śląskie, pokój ryski i nowy kształt Polski, konstytucja 1921 r. — otrzymują ledwie jednozdaniowe wzmianki. Dopiero pod koniec znajdujemy w zapiskach bardziej rozwinięte i bardziej krytyczne oceny polityki Józefa Piłsudskiego w czasie pierwszej wojny światowej i w paru następnych latach (31 V 1961).

A jednocześnie trudno nie odnotować, właśnie w związku z nowym kształtem Polski, wczesnej fascynacji morzem, w praktyce dostępnym wówczas dla warstwy zamożniejszej (i wykształconej), a więc w ówczesnych warunkach przede wszystkim dla inteligencji.

Pierwsze lata niepodległości widzą Dąbrowską w roli pracownika państwowego, przez siedem lat była bowiem zatrudniona w Ministerstwie Rolnictwa. Tu odczytujemy przekształcanie się uczuć charakterystycznych dla walki o niepodległość w ideologię „pracy dla państwa”, ale także zapis, a nawet folklor powstającej polskiej dwudziestowiecznej biurokracji.

Wiele spraw i wydarzeń umyka czytelnikowi z powodu luk w dziennikach, związanych z przejściami osobistymi, a zwłaszcza ze śmiercią Mariana Dąbrowskiego. $Z$ drugiej strony $w$ tych samych latach znaczna część notatek zawiera materiał interesujący zwłaszcza badacza intelektualnej i sentymentalnej historii pisarki, w tym dłuższe rozważania o charakterze moralno-filozoficznym, dla historii wydarzeniowej mało przydatne, a dla dziejów intelektualnych chyba mało oryginalne. Dzienniki odbijają kolejne fascynacje rzeczywistymi czy potencjalnymi partnerami i rozterki $z$ nimi związane. Wszystkie wymienione tematy znajdują miejsce i w innych partiach, ale w zapiskach sprzed 1926 r. chyba przeważają.

Następna część dzienników - wśród informacji o wielu aspektach ówczesnego życia społecznego, literackiego i politycznego — przynosi dość precyzyjny zapis przemian postawy inteligencji ( $w$ wyżej opisanym już znaczeniu tego operacyjnego dla nas terminu) wobec przewrotu majowego i nowo powstałego reżimu. Trzy lata solidarności i poparcia (1926-1928, choć już w 1927 r. występuje zgrzyt w postaci konfiskaty odezwy w obronie więźniów politycznych) dość szybko w 1929 r. przechodzą w sprzeciw, choć nie wobec reżimu jako takiego, lecz jego niektórych wykonawców, błędów ekipy rządzącej itd. Na jednej i tej samej stronie spotyka się ostra krytyka reżimu z notatką o herbatce u marszałkowej Piłsudskiej. Katalizatorem postaw jest tu myśl o przebrzydłej endecji - a nie ma innej rzeczywistej alternatywy dla rządów Marszałka. 
Z upływem czasu zagęszcza się krytyka, bo i zagęszcza się atmosfera polityczna - i policyjna - w Polsce. Z tym że wątek polityczno-krytyczny współwystępuje $z$ wątkiem literackiego sukcesu — powodzenia Nocy $i$ dni. Ten triumf literacki wywiera znaczny wpływ na samopoczucie Dąbrowskiej, ale nie na tenor jej krytyki politycznej. Rządzący reżim staje się coraz bardziej brutalny, a jednocześnie na horyzoncie pojawia się hitleryzm. W 1934 r. autorka wymienia źródła współczesnego barbarzyństwa - to jej diagnoza nadciągających chmur, które dziś nazwalibyśmy totalizmem czy totalitaryzmem: „komunizm, faszyzm, hitleryzm, obwiepol [endecki Obóz Wielkiej Polski] i bebeizm [aluzja do BBWR] - są istotnym objawem jednego i tego samego nieuchronnego najścia barbarzyństwa z rządami kliki" (8 II 1934). I jeszcze jeden cytat z tego okresu: „Polska skręci kark na sprawie chłopskiej i sprawie ukraińskiej” (21 VI 1934).

Zapiski z tych lat wyraziście ilustrują wspomnianą już ambiwalencję w stosunku do władzy i kół rządzących. Dosadna charakterystyka polityki wewnętrznej i zagranicznej (Beck jest oczywiście bête noire) przerywana jest informacjami o kontaktach ze znajomymi przedstawicielami władzy, nie mówiąc już o odzwierciedleniu w notatkach wstrząsu, którym nie tylko dla środowiska autorki była śmierć Józefa Piłsudskiego.

Narastanie nacjonalizmu i antysemityzmu, burdy młodych faszystów na uczelniach wyższych znajdują echo nie tylko w notatkach, lecz także skłaniają Dąbrowską do zabrania głosu w słynnym artykule Doroczny wstyd. Wszelkie tego rodzaju publiczne wypowiedzi budzą u autorki zawsze masę wątpliwości i obaw, a także niekończące się „za i przeciw”. Dąbrowska - i nie tylko ona boi się rozwydrzonych pałkarzy, którzy biją nie tylko studentów-Żydów, ale potencjalnie są fizycznie groźni dla wszystkich przeciwników prawicy. W ocenie kilku incydentów widać takie obawy pisarki. Tym bardziej docenić trzeba jej decyzję zabrania głosu, zarówno wtedy, jak i w innych momentach historycznych. W atakach na siły demokratyczne i liberalne wielką rolę odegrała w latach trzydziestych ofensywa kół klerykalnych, którą Dąbrowska określa jako „atak czarnych na porządnych ludzi". Podobnie jak cała ówczesna liberalno-lewicowa opinia publiczna $\mathrm{w}$ konflikcie $z$ kierunkiem prawicowo-nacjonalistycznym i faszyzującym - bo tak właśnie wówczas spolaryzowały się społeczeństwa europejskie - pisarka z zaangażowaniem popiera republikanów w Hiszpanii, odrzuca Ozon płk. Koca, który kokietuje młodych faszystów.

Wtedy właśnie powstaje Rozdroże, które stanowi wyraz radykalnych pogladów społecznych autorki - zwłaszcza na tle ówczesnych realiów i przeważających tendencji prawicowych, to też książka ta ściąga na pisarkę ataki konserwatystów i prawicy wszelkiego rodzaju. Wraz ze zbliżaniem się końca okresu międzywojennego $\mathrm{w}$ obozie rządzącym zwycięża nacjonalizm i próby dogadania się z faszyzującą częścią obozu endeckiego, co się zresztą nie udaje, ale powoduje ograniczenie wpływów „lewicy sanacyjnej”, to jest środowiska, z którym Dąbrowska była związana. Ważnym przykładem jest odwołanie wojewody 
Józewskiego z Wołynia, bliskiego przyjaciela autorki, za próby kokietowania Ukraińców.

W tym czasie następuje atak na wolnomularstwo, masonerię - nieodłączny element wszystkich kampanii prawicowych, faszystowskich i klerykalnych. Marii Dąbrowskiej, podobnie jak wielu przedstawicielom jej generacji, bliskie są oświeceniowe ideały masonerii (choć jako kobieta nie może w zasadzie aspirować do przynależności do organizacji), działalności słabej już wówczas organizacji wolnomularskiej asystuje poprzez swego partnera, Stanisława Stempowskiego, jednego z najwyższych rangą przedstawicieli rytu szkockiego w Polsce. W okresie międzywojennym występuje konflikt związany z prawicową i autorytarną ewolucją sanacji. Wielu przywódców obozu niepodległościowego należało przed 1914 r. do masonerii. Po przewrocie majowym dochodzi jednak, w ramach zabiegów o zjednanie prawicy, do opuszczenia wolnomularstwa przez piłsudczyków, a w końcu lat trzydziestych następuje atak kół rządowych na masonerię i jej rozwiązanie przez władze (choć loże wcześniej rozwiązały się same).

Szybko zbliżająca się wojna coraz bardziej zaprząta uwagę autorki. Jeszcze akcent związany z przyłączeniem Zaolzia w momencie ataku Hitlera na Czechosłowację: „Ta aneksja jest wstępem do nowego rozbioru Polski” — myśli Dąbrowska. Potem już krytyka reżimu ustępuje miejsca poczuciu wspólnoty społeczeństwa w obliczu grożącej agresji.

Początek wojny to zarazem początek przerwy $\mathrm{w}$ - znanych nam dzisiaj - notatkach dzienników. Ciąg dalszy następuje dopiero wraz z klęską Francji (czerwiec 1940 r.). Zapisy z tych czasów są bogate w informacje o szczegółach okupacyjnego życia w Generalgouvernement, ale ubogie w konkrety i nazwiska. To także czasy trudności życia codziennego, ale i turbulencji sentymentalnych. Okoliczności ograniczyły zasób informacji historycznych dostępnych dla badaczy i czytelników, nie pozwoliły autorce opisać wielu strasznych wydarzeń i obrazów widzianych czy zasłyszanych. To się nieco zmienia w 1944 r., gdy wypowiedzi Dąbrowskiej odzwierciedlają obawy większej części warstwy wykształconej przed ubezwłasnowolnieniem Polski po wojnie. Wyjątkowo interesujące dla dziejów zmieniającej się wówczas świadomości są wynurzenia na temat Żydów, ich zniknięcia i skutków tego dla Polski, a także, na tym tle, rosnącej - paradoksalnie, w warunkach wojennych — zamożności niektórych warstw społeczeństwa polskiego. Dodać możemy od siebie, że dotyczyło to powstałego wówczas nowego drobnomieszczaństwa pochodzenia wiejskiego i przedmiejskiego, które zajęło przedwojenne miejsce Żydów, a które z trudem można by zakwalifikować do klasy średniej.

Pochodzące $z$ tych miesięcy myśli Dąbrowskiej na te i zbliżone tematy, które hasłowo można by ująć: Żydzi a Polska, lud polski a kultura, kultura ludowa a przedwojenne „żydowskie Qui pro Quo i Cyruliki” (31 XII 1944), inwazja bolszewicka, Komitet Lubelski - zawierają niejedno nieoczekiwane sformułowanie, którego analiza nie jest zadaniem łatwym i każe zastano- 
wić się nad równoczesnym bytowaniem w świadomości elity inteligenckiej wielu różnych i wzajemnie wykluczających się postaw. Ale któż nie wie, że dysonans poznawczy i brak spójności sądów są zwykłymi cechami ludzkiego umysłu?

W tym momencie dziejowym otwiera się dwudziestoletnia, a dla dzienników niezmiernie płodna epoka w życiu Polski i autorki. Większość tekstu dzienników pochodzi właśnie $z$ lat 1945-1965.

Początkowe partie zapisków z tego czasu odbijają zasadniczo negatywne nastawienie wobec nowej sytuacji w Polsce i wszystkich jej aspektów, krytyczny stosunek do wszelkiej działalności, także literackiej (ostre lub drwiące słowa nawet o aktywności Kossak-Szczuckiej, nie mówiąc już o Nałkowskiej). Na jesieni 1945 r. autorka patrzy już jednak na to wszystko $z$ większym dystansem. Podkreśla szczególną wówczas aktualność słów Conrada: „Miotany sprzecznymi prądami, pozostawałem w bezruchu" (5 X 1945). A więc pojawiły się „sprzeczne prądy”, do których należy zaliczyć krzywdzące sądy emigracji o pisarzach i inteligentach ośmielających się żyć i pracować w Polsce pod rządami nowego reżimu (24 XI 1945), a także dwuznaczny stosunek emigracji londyńskiej do sprawy przynależności ziem zachodnich do Polski. Takich wypowiedzi jest coraz więcej. Mówiąc o legendach „andersowskich”, rozpowszechnianych wśród społeczeństwa, autorka konkluduje: „Nie wiem naprawdę co gorsze”. Stale w opozycji wobec nacisku promoskiewskiej władzy, aprobuje jej program społeczny (pamiętajmy, że to dopiero rok 1946) i wreszcie z rezygnacją uznaje wyniki sfałszowanych wyborów ze stycznia $1947 \mathrm{r}$. Z Rosją się nie wygra, trzeba żyć i przygotowywać się na zmiany w przyszłości, ale do tego Mikołajczyk i PSL się nie nadawali. $Z$ konfliktu światowego, o którym $z$ obawą i powątpiewaniem napomyka już w 1944 r., Polska nie wyszłaby żywa, a wywieźć 15-20 mln ludzi (sc. z Polski na Syberię) to dziś nie jest już problem. Przed wojną Polska za Becka była zależna od Niemiec, a teraz od Rosji — czy tak już być musi zawsze? (23 I 1947). Jak widać, przez dwa-trzy lata spojrzenie Marii Dąbrowskiej poważnie się zmieniło.

Tu właśnie zaczyna się okres szczególnie wyraźnej ambiwalencji w stosunku do władzy i jej organów, prasy, propagandy i wydawnictw. Dąbrowska wspomina, że w ramach reżimu i ona prosperuje (20 II 1948), a we współpracy z „reżimowymi" pismami nie widzi nic szczególnego. Widać też, wśród wyrzutów sumienia, jak jest ustępliwa w kontaktach z czynnikami cenzurującymi jej teksty aktualne i dawne. Bo też i choć „ich” celem jest sowietyzacja, „bezstronność każe przyznać, że w ciągu tych trzech lat zrobiono w wielu dziedzinach więcej rzeczy pozytywnych, niż w ciągu 20 lat niepodległości” (14 VI 1948). W tym też czasie powstaje charakterystyczna notatka, w której zostaje podkreślona rola elity w dziele ocalenia substancji polskiego społeczeństwa. Już w starożytnej Grecji, pisze Maria Dąbrowska, wielcy mówcy proponowali oprzeć się albo na Persach, albo na Macedończykach. „Kompromis jest sprawą intelektu, jest przygodą człowieka myślącego. Ale tragedią jego jest, jeśli nie rozpozna, gdzie 
się kończy" (25 VI 1948). Notabene właśnie wtedy autorka rozpoczyna pracę nad Przygodami człowieka myślacego...

Tymczasem jednak kompromis staje się coraz trudniejszy, bo po okresie pseudodemokratycznym następuje zaostrzenie reżimu, który jawnie deklaruje przebudowę Polski w duchu rosyjskiego komunizmu. Symbolicznym wydarzeniem jest „zjazd zjednoczeniowy” PPR i PPS, w istocie rzeczy włączenie resztek PPS do partii tworzonej przez PPR. Było to zarazem proklamowanie w Polsce państwa komunistycznego, którego głównym czynnikiem miała być tworzona przez „zjednoczenie” monopartia komunistyczna.

„To się odbywa jedna $z$ wielkich przemian, które niosą $\mathrm{w}$ sobie rzeczy złe pomieszane z dobrymi” (19 XII 1948) - pisze autorka; „po pewnym namyśle i wahaniu postanowiłam pójść". Można się tu uśmiechnąć: kto zlekceważyłby takie zaproszenie, nie mógł spodziewać się niczego dobrego!

Już wcześniej Maria Dąbrowska wykonuje zamówienie związane ze zjazdem intelektualistów we Wrocławiu, który — jak pisze — był skierowany tylko przeciwko wojnie akurat niewygodnej dla Moskwy. Autorka bije na alarm: „Rosja może dokonać o wiele skuteczniej tego, co nie udało się Niemcom. Za kilkadziesiąt lat Polska może za jej sprawą przestać istnieć". A jednak bierze udział w niewątpliwie dyktowanej z Moskwy imprezie zjednoczeniowej partii, którą jednocześnie wyśmiewa $\mathrm{w}$ dziennikach. $\mathrm{Z}$ dzisiejszej perspektywy łatwo wytrząsać się nad słabością charakteru intelektualistów. Ale ten, kto wtedy obserwował świat, i ten, kto uważnie czytał wtedy dzienniki, zdaje sobie sprawę, że w danym momencie świat „kapitalistyczny”, antykomunistyczny, nie przedstawiał się zbyt pociągająco, nie wykazywał wcale swej wyższości gospodarczej, która pokazała się później, i zdawał się nie być pewien swej przyszłości. To właśnie oddziaływało na wypowiedzi Marii Dąbrowskiej.

Podobnie ktoś, kto oceniałby wedle dzisiejszych pojęć wynurzenia autorki na temat Żydów, głównie, choć nie wyłącznie, żydowskich aparatczyków, popełniłby grzech anachronizmu, nawet gdy czyta, że z okazji zjazdu literatów w Szczecinie pisarka słyszy w tamtejszej dzielnicy żydowskiej „zaflegmiony szwargot” — zwrot, który przypomina język przedwojennego „Warszawskiego Dziennika Narodowego". A parę zdań dalej widzi, że Dąbrowska wywodzi wojewodę Borkowicza (choć to „Żyd-komunista”) od jakiegoś Wojsława czy Skarbimira, wojewody Bolesława Krzywoustego, którego następcą jest właśnie obecny polski wojewoda.

Łatwo byłoby tu drwić z autorki, z jej rozterek i słabości. Ale i w tym była przedstawicielką swego środowiska. Maria Dąbrowska jednak dość precyzyjnie odważa nie tylko swe gesty, ale i sądy. Najbardziej się niepokoi przemianami dokonującymi się głęboko i w sposób zinternalizowany, które według jej oceny zagrażają istocie narodu. „Właściwie naszą ojczyzną jest pewna forma życia i obyczajowości, która nam odpowiada. Gdy żyje - sprawy granic czy niepodległości dają się znieść bez utraty nadziei. Otóż ta forma, ten kształt obyczajowości, osobowości narodu jest obecnie gwałcony i poniewie- 
rany. I to jest najgorsze do zniesienia. To obrzydza nawet zbawcze reformy" (30 XII 1948). W tej optyce zjazdy intelektualistów czy nawet zjazd PZPR, wszystkie te właściwie symboliczne imprezy miały niewielkie znaczenie wobec poważniejszego zagrożenia. Często przychodzą napady obrzydzenia: „Czuję się strasznie nędzna, słaba i zastraszona w tej diabelskiej grze Żydów i bolszewików sprzysiężonych na szkalowanie Polski. Czuję jak się zanurzam w tej gnojówce [...] Jakież ja ponoszę konsekwencje? Włos mi nie spada z głowy, tyle że nic nie piszę prawie, nie mogąc pisać jak bym chciała" (16 I - 1 II 1949). Publikowane przez siebie teksty określa jako słabo odbijające jej prawdziwe myśli (30 III 1949). W tym obrzydzeniu zastanawia jednak się, co by zostało z Polski w razie zwycięstwa Zachodu w ewentualnym konflikcie - byłoby to często przywoływane i później Księstwo Warszawskie, czyli Polska kadłubowa, bez Zachodu i Wschodu.

Te myśli wiążą się jakoś z coraz częstszymi zaproszeniami płynącymi z najwyższego szczebla władzy (to wtedy Dąbrowska przekracza próg gmachu Prezydium Rady Ministrów i wstępuje na trybunę, z której władza przyjmuje pochód pierwszomajowy). Zaczyna się również dla autorki Nocy $i$ dni okres względnej pomyślności materialnej dzięki wysokim honorariom za ogromne nakłady. Od 1954 r. mieszka w nowym apartamencie na Mokotowie, w 1956 r. kupuje dom w Komorowie, w którym wkrótce zamieszka, i samochód (wartburga).

Jednocześnie podkreśla, że każdy musi w tym systemie uprawiać kamuflaż, musi postępować tak a nie inaczej i nie należy potępiać ludzi — „wyjąwszy notorycznych zbirów" - za służalcze wystąpienia publiczne. Oni tak muszą czynić. Te wystąpienia są także jakimś elementem gry i poniekąd walki o zachowanie duszy narodu. Gdy radio Madryt mówi o milczeniu Marii Dąbrowskiej jako znaku sprzeciwu, autorka oponuje: „Ja nie milczę, tylko z trudem usiłuję się przedzierać przez cenzurę" (10 I 1951).

Zgodnie z ówczesnym importowanym z Moskwy rytuałem Dąbrowska otrzymuje „przydział” fabryki, w której przeprowadza studia nad współczesnością, przetwarzaną potem przez „inżenierow czełowieczeskich duszej” na socrealistyczne utwory. W wypadku Marii Dąbrowskiej - a zresztą większości wysyłanych tak literatów - nic z tej przyszłej „twórczości” nie wyszło.

Całość uwag autorki z tych lat obraca się między stałą i najostrzejszą krytyką reżimu - przede wszystkim z pozycji obrończyni i przedstawicielki narodu zniewolonego i okupowanego przez Rosję, jej bolszewików i nasłanych przez nich Żydów ( $z$ upływem czasu w latach pięćdziesiątych ten ostatni wątek nieco się zaciera) - a niezbyt częstymi, ale bardzo charakterystycznymi uwagami o pozytywnych stronach czy osiągnięciach systemu, który obala bariery awansu mas ludowych i usuwa nadużycia kapitalizmu. Ten ostatni termin ma nie tylko u Marii Dąbrowskiej w tych latach brzmienie zdecydowane niegatywne. Znów trzeba podkreślić, że ocenianie ówczesnych kategorii pojęciowych z pozycji współczesnych byłoby anachronizmem. Trzeba było jawnego i długiego pasma sukcesów ekonomicznych i cywilizacyjnych Zachodu, by „kapitalizm” znalazł 
uznanie u polskiej klasy wykształconej. Ale to się stało w czasach znacznie późniejszych niż ostatnie dziesięciolecie życia Marii Dąbrowskiej.

Anachroniczne byłoby także rozpatrywanie wśród dzisiejszych konotacji wypowiedzi autorki o marksizmie. Dąbrowska - podobnie jak w czasach Polski Ludowej znaczna część polskiego świata intelektualnego, a zwłaszcza naukowego, jeszcze wiele lat po śmierci pisarki - uważała tę doktrynę za całkiem przydatną do naukowej analizy życia społecznego, w tym literatury (12 XI 1951) Odrzucała oczywiście funkcję liturgiczno-ideologiczno-polityczną marksizmu, ale nie znajdziemy u pisarki bliższej definicji i rozwikłania splotu tych funkcji, które ówczesny marksizm w rzeczywistości pełnił. Parę lat później, już po XX Zjeździe KPZR, napisze: „Przewiduję, że nadejdzie czas, gdy będzie można i będzie należało bronić marksizmu - sprowadzonego do jego właściwych proporcji" (7 V 1956). Prorocze słowa!

Po osobistym wstrząsie, jakim był zgon Stanisława Stempowskiego na początku 1952 r., pisarka wraca do ambiwalentnego widzenia ówczesnej rzeczywistości. Oto porównuje Pałac Kultury i Nauki do soboru prawosławnego na Placu Saskim, w tym samym czasie spotyka się z ukrywającym się Henrykiem Józewskim, a jednocześnie na sześćdziesiąte urodziny Bieruta bierze udział w przyjęciu (cóż, nieprzybycie na takie zaproszenie mogło być katastrofą i końcem!). Każdy krok pociągał za sobą dalsze - tu się kryje tajemnica różnych trudnych do wytłumaczenia dzisiejszemu czytelnikowi działań. „Modzelewscy mnie zapytali, czy nie mam nic przeciwko temu, żeby «być przedstawioną». Cóż można na takie pytanie odpowiedzieć, kiedy się już weszło w kabałę? "Proszę bardzo»" (2 V 1952). Bierut prawi komplementy, ale to wszystko ma pewno jakiś związek z częstszymi teraz $\mathrm{w}$ dzienniku wypowiedziami o pozytywnych stronach reżimu, mimo jego zależności, prymitywizmu i brutalności. To wtedy (kilkakrotnie w różnych wersjach powtórzone) padają słowa: „Z dwu beznadziei mniej beznadziejne są chyba błędy komunistów". Często jednak reflektuje się wyznając, że jest ją łatwo ująć i rozbroić: „Próżność?” (22 VII 1952). A w miejsce „Żydów-bolszewików” pojawia się pochwała (ex re Sigalina) „dobrego aliażu" polskiej i żydowskiej krwi. System trzyma się na Rosji i UB, mówi do siebie autorka, ale ani ona, ani „nikt rozsądny” nie zrezygnuje z głównych osiągnięć tego czasu. A gdy urządzają „wybory” (jest rok 1952) i są one rodzajem cyrkowego przedstawienia, komentarz Marii Dąbrowskiej brzmi: „W gruncie rzeczy nie wierzę, aby gdziekolwiek jeszcze możliwe były prawdziwe i uczciwe wybory parlamentarne" (28 XI 1952). Widzi zresztą w Polsce dominację „czarnej reakcji”, która weźmie władzę, gdy upadnie komunizm, bo ona właśnie, ta reakcja ,jak się zdaje jest istotą Polski”.

Ostatnie paroksyzmy epoki Stalina („spisek żydowskich lekarzy”) nie zmieniają sytuacji. Dąbrowska pisze nawet wypowiedź na śmierć Stalina. System stalinowski zaczyna się chwiać $\mathrm{w}$ niektórych swych ogniwach, co z pewnym, niewielkim opóźnieniem znajduje odbicie $\mathrm{w}$ stosunkach polskich. $\mathrm{Na}$ razie „podstawowa linia” komentarzy Dąbrowskiej o bieżących wydarzenich nie 
ulega zmianie. Nie narusza jej na przykład powstanie w Berlinie, wywołane - jak pisze - przez okrutny reżim, ale i tak „wedle prawdopodobieństwa racja przyszłości jest po stronie Rosji" (19 VI 1953). Chodzi tu nie o jakąś rację moralną, ale o perspektywę przewagi w ówczesnym świecie. Tymczasem autorka tak charakteryzuje sytuację polityczną: „Inteligencja «współpracuje» pełna wewnętrznych albo jawnych zastrzeżeń, naród w olbrzymiej większości wciąż mówi i myśli - nie" (3 IV 1954). Ta ocena jest bardzo istotna dla ówczesnej historii społeczno-politycznej, odzwierciedla także postawę pisarki, która przyznaje, że jej stanowisko podziela tylko mniejszość społeczeństwa. A jednak nadal wierzy, że w razie wojny wygrałaby Rosja (13 VIII 1954).

Nadchodzą czasy krytyki reżimu stalinowskiego, płynącej głównie z wewnątrz partii. „A ja jeszcze nie wierzę w ten cały kurs liberalny” (24 IV 1954). Bezpartyjni dziwią się, że partyjni inteligenci tak zmienili poglądy polityczne. Sama Dąbrowska, która właśnie otrzymała nagrodę państwową I stopnia, może patrzeć na to z pewnego dystansu wyznaczonego przez jej tak wysoką pozycję, jej wypowiedzi zamieszcza każda gazeta, po szesnastu latach rozmawia przez telefon z Jerzym Stempowskim mieszkającym w Bernie, to do niej zwraca się o interwencję żona Mariana Spychalskiego, który wciąż siedzi w więzieniu (20 IX 1955), wyjeżdża do Szwajcarii i Szwecji, Wielkiej Brytanii i Francji (przestaje to już być wówczas ewenementem, przynajmniej wśród artystów i naukowców).

Fragmenty dzienników z roku 1956 i lat późniejszych są historycznie bardzo ważnym zapisem procesów i prądów umysłowych i społeczno-politycznych występujących wśród decydującej części ówczesnej warstwy wykształconej w Polsce. Towarzyszy ona Gomułce w drodze do władzy początkowo $z$ wielką życzliwością, później z rozczarowaniem. Zwraca uwagę zmiana perspektywy w ocenie Żydów, którzy (choć późno) przodują w krytykowaniu Rosji i ostrzeganiu przed nią. Bo też i antysemityzm był wówczas orężem konserwy partyjnej („Natolin”, „gazrurka”-Witaszewski). Odtąd pojawiają się zaskakująco pozytywne oceny ludzi pochodzenia żydowskiego (określanych nieraz jako „Polacy żydowscy”), a przeciwstawianych raz i drugi gorszym pod względem stosunku do innych Polakom.

Krytyka władzy u Dąbrowskiej, w odróżnieniu od tych nowych przeciwników partii, jest jednak umiarkowana, nie podziela ona też ostrego krytycyzmu „bytowego" szerszych środowisk, które żądają podniesienia poziomu życiowego. „W tej chwili wściekłość ogarnia ludzi nie że mają źle (a kiedyś mieli w Polsce dobrze), tylko że nie mają wszystkiego ściśle tak jak w Ameryce" (7 II 1958) - stwierdza z pewną przesadą. Trzeba tu zauważyć, że Maria Dąbrowska należy nie tylko do określonego środowiska, lecz także do starszego pokolenia, któremu na ogół dalej idące aspiracje młodszych pokoleń wydają się nadmierne. W notatkach przeważa pozytywne widzenie sytuacji w Polsce, w czym — jak pisze — sekunduje jej Juliusz Poniatowski, który niedawno wrócił 
z emigracji. Na porządku dziennym znajduje się wówczas Nobel dla Pasternaka - w tej sprawie stanowisko Dąbrowskiej było bardzo wyważone i ostrożne. Inna kwestia to stosunki władzy z Kościołem, na który zawsze autorka patrzyła krytycznie, uważając go za czynnik zacofania i nienawiści do „innych”; widziała jednak także, że nastawienie religijne ludności i lata prześladowań dają tej instytucji ogromny kredyt zaufania w społeczeństwie.

Stopniowo inteligencja twórcza $\mathrm{w}$ sposób nieunikniony popada $\mathrm{w}$ konflikt z władzą. W 1959 r. dochodzi już do poważniejszych starć na tle prób narzucania przez partię składu kierownictwa Związku Literatów. Autorka częściej teraz wyjeżdża zagranicę, spotyka się z emigrantami, głównie z kręgu „Kultury” i notuje: „Wszyscy emigranci namawiają mnie na miłość do Rosji [...]. Ale żaden $z$ nich nie wyprowadza stąd jedynej dla siebie konsekwencji: wrócić i szerzyć tę koncepcję w Polsce" (29 IV 1960).

Aktywność Dąbrowskiej zaczyna ograniczać choroba i szpital. Pogarszająca się gospodarka tych lat potęguje codzienne trudności, nawet na poziomie bytowym pisarki, właścicielki domu w Komorowie i mieszkania w Warszawie.

Pesymistycznie wyraża się Maria Dąbrowska, i to wielokrotnie, o poziomie umysłowym szerszych warstw społeczeństwa w Polsce, a to przy okazji ordynarnych i prymitywnych wystąpień Chruszczowa na arenie międzynarodowej i przeciw sztuce nowoczesnej. Sądzi, że te drobnomieszczańskie gusty i umysłowość Chruszczowa bliskie są znacznej części społeczeństwa także w Polsce (18 III 1963).

W końcu spięcie wokół „listu 34” doprowadza do udziału w proteście. Podpisujący trafiają na listę proskrypcyjną, z której jednak wyłączono Dąbrowską, Parandowskiego i Dygata. Władze musiały się jednak liczyć z najbardziej popularnymi postaciami literatury. Stanowisko pisarki było pełne godności i umiaru. Ale postępująca choroba coraz bardziej ograniczała jej aktywność.

Warto zauważyć, że ambiwalentny stosunek do władzy: ostra krytyka i sprzeciw powierzane głównie dziennikowi, a zarazem współistniejąca z nimi zasadnicza aprobata dla ówczesnej Polski, właśnie dlatego, że w tamtym czasie nie mogła ona być inna, i że - zdaniem autorki - dawała polskości szanse ocalenia i przetrwania ( $\mathrm{w}$ oczekiwaniu na bliżej nieokreślone zmiany $\mathrm{w}$ przyszłości) — otóż taka linia argumentacji wytworzyła się już w pierwszych latach po zakończeniu drugiej wojny światowej i przetrwała aż do końca życia diarystki. To jednak sprawa wtórna wobec wartości dzienników jako źródła historycznego, bo temu problemowi poświęcone zostały te strony. Jeśli wdajemy się w komentarze dotyczące postawy i poglądów samej Dąbrowskiej, to przede wszystkim - choć jest to temat sam przez się niezmiernie ciekawy ze względu na to, że punkt widzenia autorki dzienników musiał rzutować także na ich treść i wartość merytoryczną.

Powtórzmy raz jeszcze konkluzję zawartą w treści tych rozważań: udostępnienie oryginalnego tekstu dzienników Marii Dąbrowskiej w postaci najbardziej wygodnej badaczom historii, dziejów kultury, językoznawcom i innym 
specjalistom będzie wydarzeniem w polskiej kulturze i podnietą dla prac z wielu dziedzin polskiej humanistyki.

1 października 2007 r.

\section{MARIA DĄBROWSKA'S DIARIES AS A SOURCE OF HISTORICAL KNOWLEDGE}

\section{Summary}

The author considers the diaries of Maria Dąbrowska covering the period 1914 to 1966 which have recently been made available in electronic form and recognises her as the most important Polish storyteller of the first half of the $20^{\text {th }}$ century. He considers the importance of this work to research into the history of Poland during the $20^{\text {th }}$ century. He emphasises Maria Dąbrowska's specific view of political and social reality, which is not surprising given that she was a leading intellectual and artist. However, the diaries are not just a reflection of the author's personality but they also illustrate the attitudes that part of the Polish intelligentsia which during the years prior to independence in 1989 was called the "independence intelligentsia". This was a community which was largely liberal and left-wing whose views were shaped by concepts adopted at the turn of the $19^{\text {th }}$ and $20^{\text {th }}$ centuries. A broad spectrum of Polish society did not fully accept the views of that community. Nevertheless, at critical times (e.g. the invasion of Poland in 1939, resistance against the Germans in 1939-1944 or the communist crisis in 1956) Maria Dąbrowska's diaries reflect the attitudes of most Poles. The diaries shed light on the situation and attitudes of the intelligentsia and intellectuals during the communist era and their attitudes to the authorities and the communist or socialist social and political programme.

\section{Key words/słowa kluczowe}

Maria Dąbrowska; Polish literature in the twentieth century / literatura polska $\mathrm{XX}$ wieku; intelligentsia/intellectuals / inteligencja; social and moral liberalism in Poland / społeczny i moralny liberalizm w Polsce; Marshall Piłsudski political followers / stronnictwo marszałka Piłsudskiego; communism in Poland / komunizm w Polsce 